\title{
Water Resources of Uganda: An Assessment and Review
}

\author{
Francis N. W. Nsubuga1,2*, Edith N. Namutebi3 ${ }^{3}$, Masoud Nsubuga-Ssenfuma ${ }^{2}$ \\ ${ }^{1}$ Department of Geography, Geoinformatics and Meteorology, University of Pretoria, Pretoria, South Africa \\ ${ }^{2}$ National Environmental Consult Ltd., Kampala, Uganda \\ ${ }^{3}$ Ministry of Foreign Affairs, Kampala, Uganda \\ Email: ${ }^{*}$ nwasswa@gmail.com
}

Received 1 August 2014; revised 26 August 2014; accepted 18 September 2014

Copyright (C) 2014 by authors and Scientific Research Publishing Inc.

This work is licensed under the Creative Commons Attribution International License (CC BY).

http://creativecommons.org/licenses/by/4.0/

(c) (7) Open Access

\begin{abstract}
Water resources of a country constitute one of its vital assets that significantly contribute to the socio-economic development and poverty eradication. However, this resource is unevenly distributed in both time and space. The major source of water for these resources is direct rainfall, which is recently experiencing variability that threatens the distribution of resources and water availability in Uganda. The annual rainfall received in Uganda varies from $500 \mathrm{~mm}$ to $2800 \mathrm{~mm}$, with an average of $1180 \mathrm{~mm}$ received in two main seasons. The spatial distribution of rainfall has resulted into a network of great rivers and lakes that possess big potential for development. These resources are being developed and depleted at a fast rate, a situation that requires assessment to establish present status of water resources in the country. The paper reviews the characteristics, availability, demand and importance of present day water resources in Uganda as well as describing the various issues, challenges and management of water resources of the country.
\end{abstract}

\section{Keywords}

Water Resources Management, Water Resources Utilisation, Climate Change, Water Resources Development, Uganda

\section{Introduction}

Of all the renewable resources, water has a unique place. It is essential in sustaining all form of life, food production, promoting economic development and for general wellbeing. Water is impossible to substitute for most of its uses, difficult to de-pollute, expensive to transport but a manageable natural resource capable of diversion,

\footnotetext{
${ }^{*}$ Corresponding author.
}

How to cite this paper: Nsubuga, F.N.W., Namutebi, E.N. and Nsubuga-Ssenfuma, M. (2014) Water Resources of Uganda: An Assessment and Review. Journal of Water Resource and Protection, 6, 1297-1315. 
transport, storage and recycling [1]. There are two distinct water resources categories (surface and ground water) which are part of the earth's hydrologic cycle. Surface and groundwater resources play a major role in domestic water supply, watering livestock, industrial operations, hydropower generation, agriculture, marine transport, fisheries, waste discharge, tourism, and environmental conservation. The water resources of a region, conceived as a dynamic phase of the hydrologic cycle are influenced by climatic, physiographic and geological factors [2]. Orography on the other hand, plays a significant role in influencing rainfall and other climatic elements (temperature, humidity and wind) that affect evapo-transpiration, which determines the totality of water resources [2].

Water resources in Uganda comprise of large lakes like; Lake Victoria, Kyoga, Albert, George and Edward; wetlands and rivers, such as the Nile River, Katonga, Semliki, Malaba; rainfall, surface water runoff and ground water [3]. Two or more of these water resources are shared by other riparian states that are part of the Nile Basin, shown in the (Table 1). In a regional context, the whole of Uganda's water resources is part of the Nile. Uganda is a downstream riparian to Burundi, Democratic Republic of Congo (DRC), Kenya, Tanzania and Rwanda and an upstream riparian to South Sudan, Sudan and Egypt [4].

Much of the literature on water resources in Uganda is scattered and embedded in policy documents, strategic plans and reports produced by consultants and international organisations. There are also several issues and challenges surrounding water resources, which are aggravated by climate change and variability and population growth among others. The current water management practices in Uganda may not be robust to cope with these challenges which impact on water resources and increase water use requirements. With rapid growing population and improving living standards, the pressure on Uganda's water resources is increasing and per capita availability of water resources is reducing day by day. Spatial and temporal variability in precipitation is another challenge the country faces, which often result into floods, landslides and droughts. The quality of surface and ground water resources is also deteriorating because of increasing pollutant loads and non-point sources. Climate change is expected to impact on rainfall and water availability. Currently, the data collection, processing, storage and dissemination have not received the deserved attention. All these aspects require an assessment of the current water resources status. The review therefore, focuses on the character, potential, governance, challenges, availability and demands of water resources of the country using secondary data sources.

\section{Hydrology of Uganda}

\subsection{Surface Water Resources}

Uganda is a landlocked country that occupies $241550.7 \mathrm{~km}^{2}$ of land. Open water and swamps constitute 41743.2 $\mathrm{km}^{2}$ of area [4], with about $16 \%$ of total land area of wetlands and open water, plus the annual water supply of $66 \mathrm{~km}^{3}$ in form of rain and inflows. One would therefore conclude that, Uganda is fairly well endowed with water resources. Since direct rainfall is the most important source of water resources in Uganda, understanding the

Table 1. The major shared water bodies and river courses of Uganda.

\begin{tabular}{ccc}
\hline Water resource & Countries sharing & Basin wide \\
\hline River Nile & Uganda, South Sudan, Sudan, Egypt & $\begin{array}{c}\text { Burundi, DRC, Egypt, Ethiopia, Kenya, Rwanda, South Sudan, } \\
\text { Sudan, Tanzania, Uganda, Eritrea } \\
\text { River Achwa } \\
\text { River Kagera }\end{array}$ \\
Uganda, South Sudan & Uganda, South Sudan \\
River Semliki & Tanzania, Burundi Rwanda, Uganda & Nile Basin Riparian States-Burundi, Tanzania, Rwanda, Uganda \\
River Malaba & DRC, Uganda & Nile Basin Riparian States \\
River Sio & Kenya, Uganda & Kenya, Uganda \\
Lake Victoria & Kenya, Uganda & Kenya, Uganda \\
Lake Albert & Uganda, Kenya, Tanzania & Nile Basin Riparian States \\
Lake Edward & DRC, Uganda & Nile Basin Riparian States \\
Sango Bay Swamp & DRC, Uganda & DRC, Uganda \\
\hline
\end{tabular}


spatial and temporal variability of rainfall is therefore paramount when assessing water availability [5]. Water availability has determined the local water resources, land-use potential and population distribution.

The Department of Water Resources Management of Uganda has categorized the surface water resources into eight main drainage sub-basins [4]. These include; Lake Victoria, Lake Kyoga, River Kafu, Lake Edward, Lake Albert, River Aswa, Albert Nile and Kidepo Valley (Figure 1). The yield from these sub-basins, though small compared with the total Nile flow, dominates the water resources potential with in Uganda. Major water bodies include lakes Victoria, Kyoga, Albert, George, Edward (Table 2) and another 149 smaller lakes spread across the country covering an area of $38,500 \mathrm{~km}^{2}$ [3]. The lakes are interconnected by a river system, which developed as a result of river reversal and ponding that formed the two major lakes [6] (and references there in). In the north-eastern part of the country, many of the water courses are seasonal. The main river basins of Uganda are

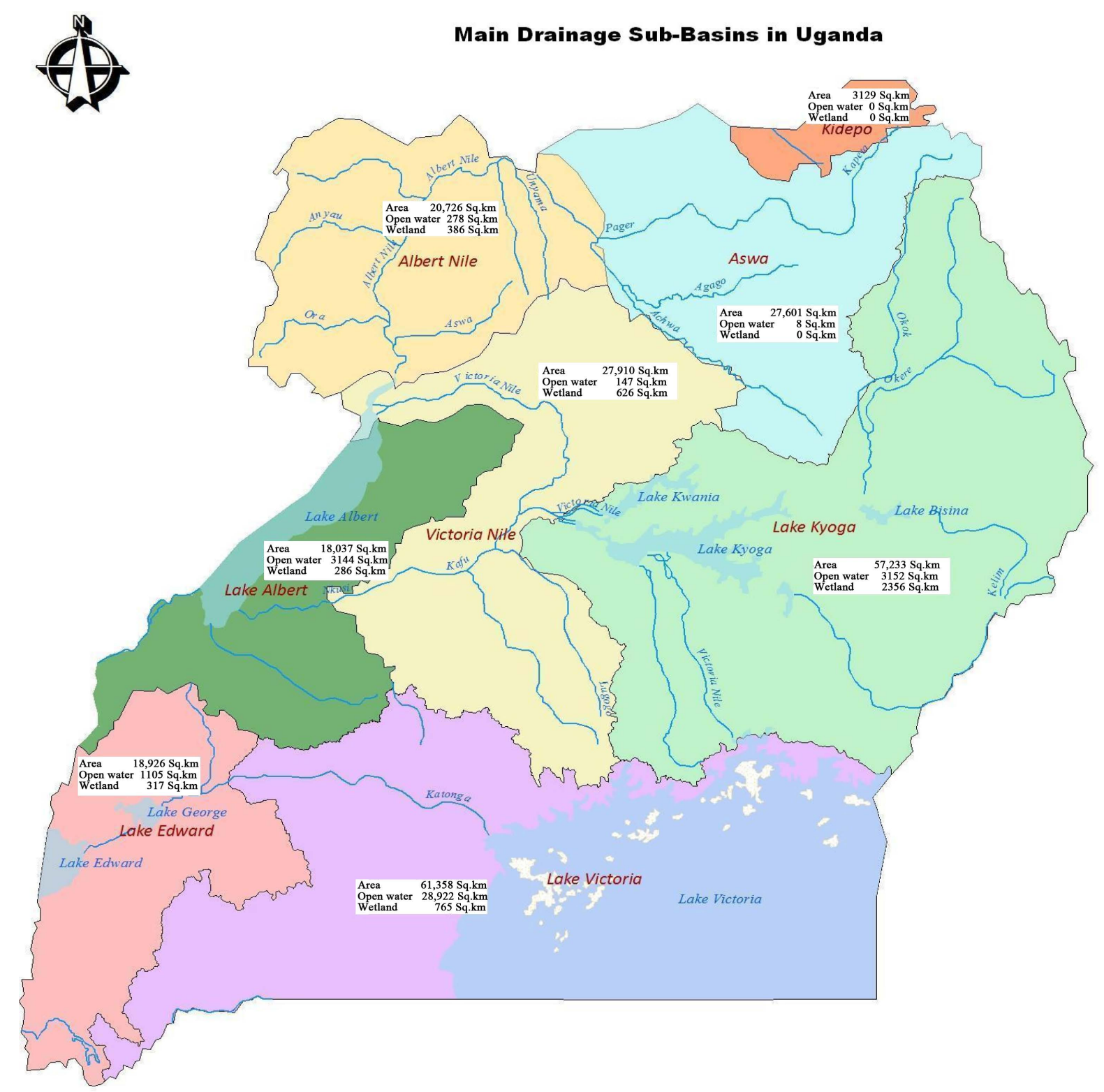

SOURCE: Uganda National Water Development Report- 2005, modified to suit study

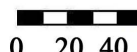

80

Figure 1. Main drainage sub-basins in Uganda including rivers and lakes. 
Table 2. Major Lakes of Uganda and their associated characteristics.

\begin{tabular}{|c|c|c|c|c|c|c|}
\hline & $\begin{array}{c}\text { Surface } \\
\text { Area }\left(\mathrm{km}^{2}\right)\end{array}$ & $\begin{array}{l}\text { Area in Uganda } \\
\left(\mathrm{km}^{2}\right)\end{array}$ & $\begin{array}{l}\text { Mean Elevation above } \\
\text { Sea Level (m) }\end{array}$ & $\begin{array}{l}\text { Maximum } \\
\text { Depth (m) }\end{array}$ & $\begin{array}{c}\text { Volume in } \\
\text { Uganda }\left(\mathrm{km}^{3}\right)\end{array}$ & $\begin{array}{c}\text { Mean } \\
\text { Depth (m) }\end{array}$ \\
\hline Lake Victoria & 68,800 & 28,655 & 1134 & 84 & 1237 & 40 \\
\hline Lake Albert & 5659 & 2850 & 618 & 56 & 80 & 25 \\
\hline Lake Kyoga & 2636 & 2636 & 1034 & 10.7 & 7.9 & 3 \\
\hline Lake Edward & 2324 & 638 & 912 & 117 & 16.8 & 34 \\
\hline Lake Kwania & 540 & 540 & 1033 & 5.4 & 2 & 4 \\
\hline Lake Wamala & 250 & 250 & 1290 & 9 & 1.2 & 4 \\
\hline Lake Bisina & 150 & 150 & 1030 & N/A & 0.5 & N/A \\
\hline Lake George & 228 & 228 & 914 & 7 & 0.8 & 2.4 \\
\hline Lake Bunyonyi & 61 & 61 & 1974 & 39.3 & 0.2 & \\
\hline Lake Kachira & 39.6 & 39.6 & 1235 & 4.8 & 0.2 & \\
\hline $\begin{array}{l}\text { Other } 149 \text { Minor } \\
\text { Lakes }\end{array}$ & & 2453 & & & 7.2 & \\
\hline Total & & 38500.6 & & & 1353.8 & \\
\hline
\end{tabular}

Source: UN-Water, 2006 in [6].

shown in the Figure 1.

The most prominent hydrological feature in Uganda is Lake Victoria, which is the second largest fresh water lake in the world [7], with an area of $69,000 \mathrm{~km}^{2}$. River Nile, which is the only outflow from the lake, has its source at the point where Lake Victoria spills over Ripon Falls. The $130 \mathrm{~km}$ stretch of the Nile from Lake Victoria to Lake Kyoga is termed the Victoria Nile. Lake Kyoga is drained through the Kyoga Nile which, after a relatively flat reach downstream from the lake, enters a series of rapids and falls before it flows into Lake Albert at a level $410 \mathrm{~m}$ lower than Lake Kyoga. The plateau immediately to the north of the Rwenzori drains to Lake Albert via the Muzizi River.

In Lake Albert, the Nile is joined by river Semliki which drains Lakes George \& Edward found in the rift valley and the high rainfall area of the Rwenzori Mountains. Lakes George \& Edward are connected through the Kazinga Channel. The Nile flows from Lake Albert with a gentle slope to the Sudanese boarder. This reach of the river is called the Albert Nile.

Major rivers include the Nile, Ruizi, Katonga, Kafu, Mpologoma and Aswa. The rivers and lakes of Uganda are within the upper part of the White Nile Basin [4], with the exception of those in the tiny North-eastern catchment of Kidepo, which drains into the Lake Turkana basin in Kenya (Figure 1). The North-western slopes of Rwenzori watershed in Uganda drain to Lake Edward via the Ishasha, Chiruruma, Nchwera and Nyamweru rivers, and also by several streams, which enter the western flowing part of the Katonga River. The North-eastern part of the Virunga range watershed however, drains directly to Lake Victoria via a series of swampy lakes and streams culminating in the Kibaler River, which enters Lake Victoria through the swamps at Sango Bay [8]. The Ugandan slopes of Mt. Elgon and the central highlands along the Kenyan border drain via rivers with swampy valleys or seasonal floodplains to Lake Kyoga, while the north eastern highlands and most of the northern plateau drain directly to the Bahr el Jebel in Sudan via the Achwa River that also joins the Nile.

Because of warping of the landscape, many of the perennial streams of the plateau are clogged with swamp [6]. About 10 Percent of the country is covered by swamps (wetlands), of which one third is permanently inundated. In the south and west of the country, swamps form an extensive low gradient drainage system in steep V-shaped valley bottoms with a permanent wetland core and relatively narrow seasonal wetland edges. In the north, they mainly consist of broad flood plains. In the east they exist as a network of small, vegetated valley bottoms in a slightly undulating landscape [6].

\subsection{Wetland Resources}

There are basically two broad distributions of wetland ecosystems in Uganda: 1) the natural lakes and lacustrine 
swamps found around major lakes; 2) the riverine and flood plain wetlands which are associated with the major river systems in Uganda. Wetlands, cover about, $29,000 \mathrm{~km}^{2}$, or $13 \%$ of the total area of the country [9]. The wetlands comprise swamp $\left(8832 \mathrm{~km}^{2}\right)$, swamp forest $\left(365 \mathrm{~km}^{2}\right)$ and sites with impeded drainage $\left(20,392 \mathrm{~km}^{2}\right)$. Wetlands also include areas of seasonally flooded grassland, swamp forest, permanently flooded papyrus, grass swamp and upland bog. By 2008, the coverage had declined to 10.9\% (Table 3). This decline has been generally observed around Lake Victoria and Kyoga drainage basins. The decline according to the Uganda water and environment sector performance report of 2011 is largely attributed to encroachment for expansion of urban centres, settlement, industrial developments and extension of agricultural land. Except for Sango Bay, the bulk of Uganda's wetlands lie outside protected areas [3].

Wetlands perform a number of functions, such as; mitigating the effects of both floods and droughts, providing fish resources and support cropping and grazing along their margins. They are centres of high biodiversity and productivity as well as valuable refuges and sources of food like fish. Furthermore they are active biological filters in the treatment of effluents, but due to this function they are also sensitive to the accumulation of pollution.

\subsection{Yield of Rivers}

All rivers in Uganda ultimately reach the Nile through various interconnections. Thus an understanding of the Nile flows, gives us an insight into the flow regime of major rivers in Uganda. The flows of the Nile are highly variable from year to year. This annual variability has been monitored and reported in previous studies [3] [4] evidenced in Figure 2. The plot shows the long-term variations in flows monitored along Victoria Nile at Jinja, Kyoga Nile at Masindi Port and Albert Nile at Panyango. It shows the flow increased from 1960s, after which there is a steady decline in the flow at all monitoring points. The long-term average outflow from Lake Victoria has been $840 \mathrm{~m}^{3} / \mathrm{s}$ and the range of outflows is between a minimum of $345 \mathrm{~m}^{3} / \mathrm{s}$ and a maximum of $1720 \mathrm{~m}^{3} / \mathrm{s}$. At the $95 \%$ monthly reliability level, the flow of the Victoria Nile is of the order of $495 \mathrm{~m}^{3} / \mathrm{s}$.

Using annual rainfall data series for the period 1940 to 1999, we computed a Drought Severity Index (DSI) for the drainage sub-basins in Uganda. Results presented in Table 4 have been compared with plot in Figure 2, which was produced by DWRM. There is a close correlation between DSI and the river Nile outflows monitored for 1899-1997 period.

Table 3. Changes in wetland coverage by drainage basin between 1994 and 2008.

\begin{tabular}{cccccc}
\hline Drainage Basin & $1994\left(\right.$ Area $\left.\mathrm{km}^{2}\right)$ & $\%$ & $2008\left(\right.$ Area $\left.\mathrm{km}^{2}\right)$ & $\%$ & \% Change \\
\hline Albert Nile & 1736.3 & 6.21 & 1255.2 & 4.71 & 27.7 \\
Aswa & 3028.0 & 10.83 & 2168.9 & 8.24 & 28.4 \\
Kidepo & 168.1 & 0.60 & 197.2 & 0.74 & -17.3 \\
Lake Albert & 2838.6 & 10.15 & 2421.7 & 10.20 & 14.6 \\
Lake Edward & 1671.1 & 5.97 & 11028.5 & 41.92 & 26.5 \\
Lake Kyoga & 15008.3 & 53.67 & 3310.2 & 12.58 & 53.8 \\
Lake Victoria & 7167.6 & 25.63 & 4829.4 & 18.35 & 16.5 \\
Victoria Nile & 5786.3 & 20.69 & & & \\
\hline
\end{tabular}

Source: Uganda water and environment sector performance report, 2011—modified to suit study.

Table 4. Drought years for selected drainage sub-basins in Uganda.

\begin{tabular}{|c|c|c|c|c|}
\hline Series Variables & Climatic Normal & Albert Nile & Lake Kyoga & Lake Victoria \\
\hline \multirow{2}{*}{ Annual } & 1940-1969 & $\begin{array}{c}\text { 1943, 1949, 1952, 1953, } \\
\text { 1954, } 1965\end{array}$ & $\begin{array}{l}\text { 1943, 1949, 1953, } \\
1957,1958,1965\end{array}$ & $\begin{array}{l}1943,1946,1952, \\
1953,1959,1965\end{array}$ \\
\hline & 1970-1999 & $\begin{array}{c}\text { 1971, 1983, 1984, 1989, } \\
1993\end{array}$ & $\begin{array}{c}1973,1974,1979,1980 \\
1984,1986,1993\end{array}$ & $\begin{array}{l}\text { 1970, 1971, 1980, } \\
1982,1983,1985\end{array}$ \\
\hline
\end{tabular}


Lakes Victoria, Kyoga and Albert Outflows (m³/s) (1899-1997)

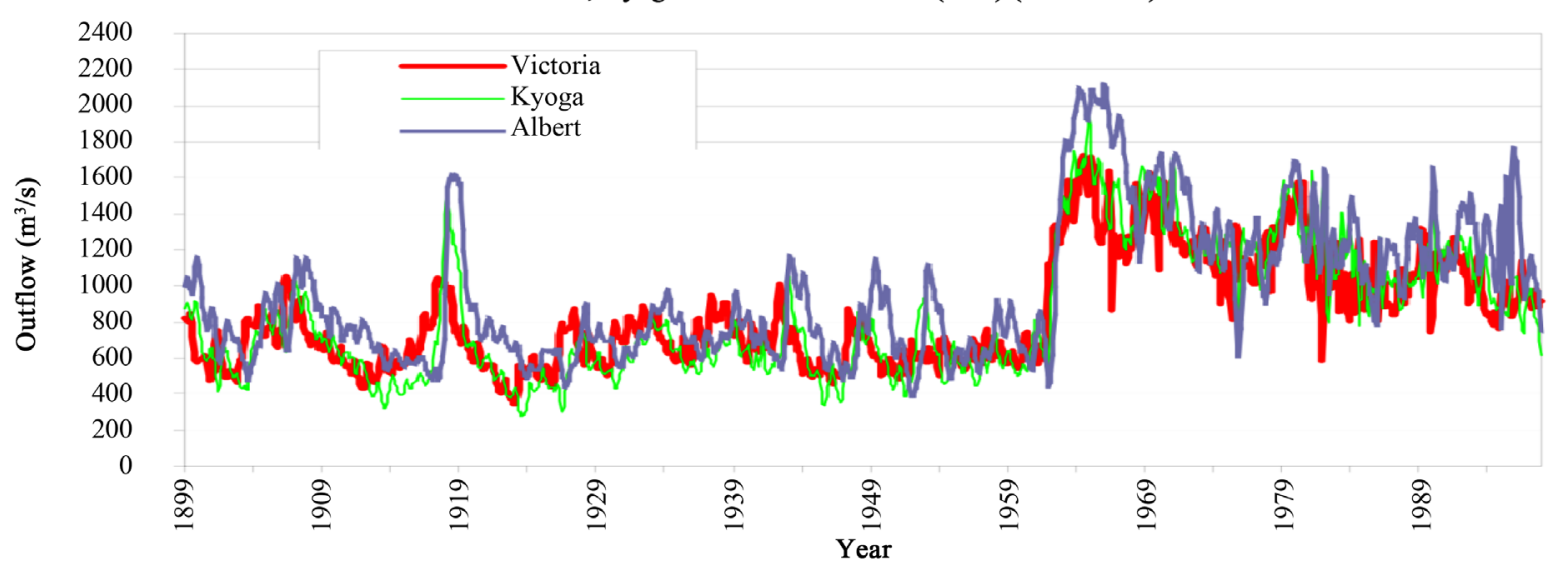

Figure 2. Long-term variations in river Nile flows (figure adopted from WRM subsector reform study report 2004).

Following steps in [10], one can discover the years and seasons when the sub-basins were experiencing droughts. It is evident from the plot (Figure 2) and Table 4 that, the early 1940s and 1950s in the first climatic normal were years of below normal rainfall. The situation is similar in the second normal when the early 1980s were drought years, consequently affecting the outflow of river Nile. This re-affirms the fact that the main source of water for the water resources in Uganda is rainfall and the whole of Uganda's water resource is part of the Nile.

Annual rainfall data for the period 1940 to 1999 were exposed to Sen's T test to establish the behavior of rainfall trends in Uganda. The results of Sen's $\mathrm{T}$ test applications to annual rainfall of the main drainage sub-basins are shown in Table 5. The Sen's T test results indicate a negative trend of annual rainfall in six of the sub-basins, namely; Albert Nile, River Aswa, Lake Albert, Lake Edward \& George, Lake Kyoga and Lake Victoria. Significant decreasing trends were observed in River Aswa and Lake Albert sub-basins. Results for Victoria Nile sub-basin show a positive trend, which is not statistically significant at 0.05 . Consequently the decreasing rainfall affects water resource distribution in the country.

Despite Uganda's significant water resources, their spatial and temporal variability often renders many parts of the country water stressed over long periods of the year. Water resource management sub-sector reform study of 2004 showed that, districts in the north-eastern and south-western parts of the country have the least per capita water availability. The study also reveals that by 2015 more than $75 \%$ of the country will be water stressed (Figure 3). The methodology used in computing the water availability only considers the runoff generated within each district. It is used here to give a picture of the average yield of major catchments in Uganda.

For example the south-western and north-eastern parts of the country have the lowest annual run-off ( $<1$ litre $/ \mathrm{s} / \mathrm{km}^{2}$ ). These are semi-arid areas, which receive very low rainfall. The Lake Victoria basin has the highest run-off ( $>10$ litres $/ \mathrm{s} / \mathrm{km}^{2}$ ) [11]. Mean annual rainfall calculated for the different drainage sub-basins during 1940 to 2009 is depicted in Figure 4. Analysis supports the correlation between rainfall and run-off generated from each sub-basin. The average yield of major catchments in Uganda is also represented in Figure 4.

A recent study by DWRM in Rwizi, Wamala and Victoria catchments, in the Victoria water management zone concluded that, reduced water levels occur annually in the dry season with in the three catchments [12]. The lowest levels are witnessed at the end of every dry season, until the rains set in, but not reaching the original high levels. This however paints a bleak picture especially when the rainy seasons become unpredictable [12].

\section{Status of Water Availability}

Two organizations, Directorate of Water Development (DWD) and National Water and Sewerage Corporation (NWSC) have been tasked to ensure that water is availed to Ugandans. Available information from NWSC shows that there has been a steady increase in total water production e.g. from $46.7 \mathrm{million} \cdot \mathrm{m}^{3} / \mathrm{yr}$, in 2000/01 to 72.14 million $\cdot \mathrm{m}^{3} / \mathrm{yr}$ in 2009/10 financial years. Comparing the water requirements with the available renewable freshwater, Uganda had a capacity to utilize only $1 \%$ of the current renewable freshwater for consumptive pur- 
Spatial Per capita Water Availability ( $\left.\mathrm{m}^{3} / \mathrm{yr}\right)$

Current (2001)

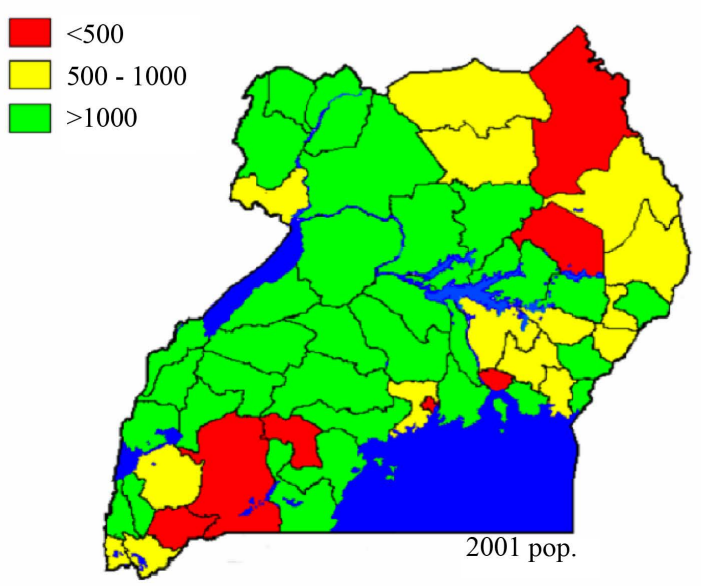

\section{Spatial Per capita Water Availability ( $\left.\mathrm{m}^{3} / \mathrm{yr}\right)$}

Projected (2015)

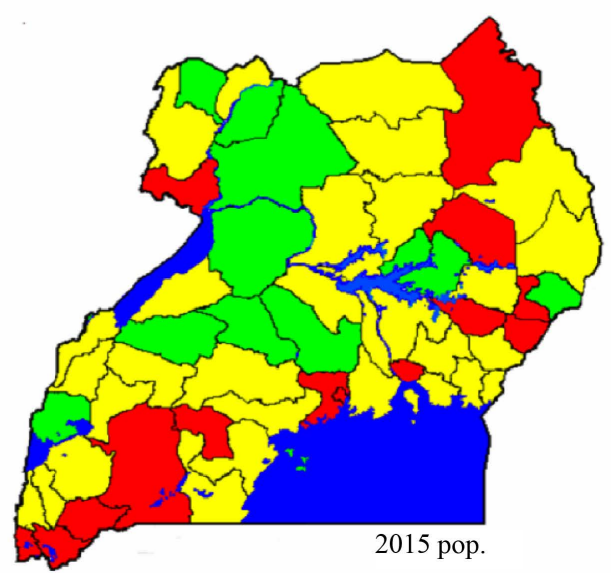

Figure 3. Spatial per capita surface water distributions (m³/yr). Source: WRM sub-sector Reform study report, 2004.

Mean Annual Rainfall in the Main Drainage Sub-Basins of Uganda

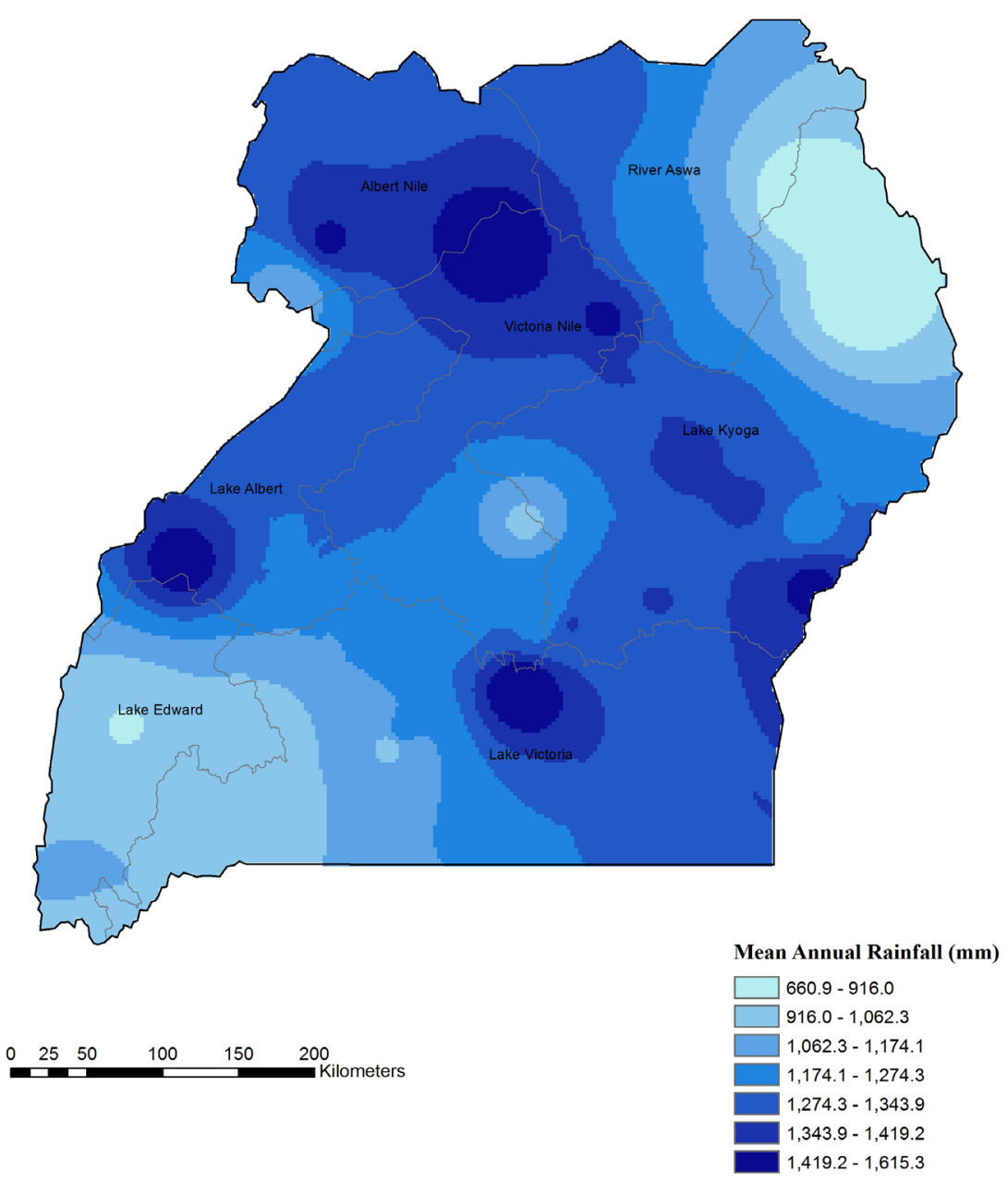

Figure 4. Distribution of Mean annual rainfall in main drainage sub-basins in Uganda 1940-2009. 
Table 5. Trend results for the main drainage sub-basins. Sen’s T-test was performed on area average rainfall data.

\begin{tabular}{ccccccccc}
\hline Sub-Basins & Rain Series & Albert Nile & $\begin{array}{c}\text { River } \\
\text { Aswa }\end{array}$ & $\begin{array}{c}\text { Lake } \\
\text { Albert }\end{array}$ & $\begin{array}{c}\text { Lake } \\
\text { Edward }\end{array}$ & $\begin{array}{c}\text { Lake } \\
\text { Kyoga }\end{array}$ & $\begin{array}{c}\text { Lake } \\
\text { Victoria }\end{array}$ & $\begin{array}{c}\text { Victoria } \\
\text { Nile }\end{array}$ \\
\hline $\begin{array}{c}\text { Year of } \\
\text { Rainfall }\end{array}$ & Maximum & 1961 & 1983 & 1961 & 1996 & 1961 & 1961 & 1961 \\
$\begin{array}{c}\text { SEN's } \\
\text { T-Test }\end{array}$ & Minimum & 1943 & 1943 & 1943 & 1979 & 1957 & 1957 & 1943 \\
\hline
\end{tabular}

poses. Out of the total water withdrawal, domestic water supply accounted for about $51 \%$, agriculture $41 \%$ and industry 8\% [8]. Withdraw per capita rose from $12 \mathrm{~m}^{3} / \mathrm{yr}$ in 2002 to $21 \mathrm{~m}^{3} / \mathrm{yr}$ in 2008 (Figure 5).

Percent change is equivalent to $112 \%$ in a seven-year period. Notable changes were realized in domestic withdrawals from $45 \%$ to $51 \%$, while industrial withdrawals fell by $7 \%$. The use of water all over the world is a function of population change, food consumption, economic policy, technology, lifestyle and societies' views of the value of freshwater. Since Uganda has one of the fast growing populations (3.2\%), its demands will lead to increased water withdrawal. For instance, total volume of water sold according to NWSC annual reports had increased from 31,151,380 million $\cdot \mathrm{m}^{3} / \mathrm{yr}$ in 2002/03 to 47,027,817 million $\cdot \mathrm{m}^{3} / \mathrm{yr}$ by June 2010 . Much of the total water produced was sold to domestic consumers (48.9\%), industrial and commercial enterprises (25.4\%), institutions and governments (20.8\%), and (4.8\%) was sold through public standpipes. This positive trend shows how effective the organizations have been in achieving national targets.

The major water sources exploited are protected springs, deep boreholes and shallow wells. These are also sources through which natives access water as individuals or licensed independent water providers. Records from water permit database of the DWRM, for example put water abstractions of registered users for the year 2003 in Lake Albert basin at $1500 \mathrm{~m}^{3} / \mathrm{yr}$ abstracted from surface water while ground water abstraction accounts for $63 \mathrm{~m}^{3} / \mathrm{yr}$. Water abstraction particularly from the Albert basin is expected to increase following the recent discovery of oil reserves. Water resources management actions within the Albert basin will require vigilance and strict monitoring during the process of drilling and processing oil.

\subsection{Groundwater Occurrence}

The primary source of freshwater for drinking and irrigation in the world is groundwater. Ground water supplies $75 \%$ of all safe sources of drinking water in Africa [13]. In Uganda for example, $61 \%$ of the country's water is from a ground water source, accessed from springs and boreholes around Lake Victoria and south-western Uganda. Several studies, like [13]-[17] have assessed ground water occurrence in Uganda from different perspectives mostly at a catchment scale. These assessment studies have been a basis for water resources planning in the country.

According to the Monitoring and Assessment Division report of 2011, ground water resources of Uganda were estimated in 2010 during the National water resources study to be as shown in Table 6 for the different basins. The report produced a map of estimated exploitable groundwater resource per district. This exploitable ground water represents the proportion of renewable resources that can be exploited on a sustainable basis without seriously affecting the environment.

The Victoria Nile and Kyoga basin have sustainable ground water, which is more than $36 \mathrm{~mm} / \mathrm{yr}$, while Kidepo has the least amount of sustainable ground water equivalent to $6.3 \mathrm{~mm} / \mathrm{yr}$ (Table 6). This is a true reflection of the catchment size from which these basins draw water (Figure 1).

\subsection{Groundwater Development}

Groundwater is the major source of water supply in the rural, semi-arid and arid areas in Uganda. Groundwater development has been going on since the 1930s through construction of deep boreholes, shallow wells and protected springs. There are approximately 20,000 deep boreholes, 3000 shallow wells and 12,000 protected springs in the country constructed mainly for rural domestic water supply. In the 1990s ground water was intensified to provide for town water supply. For example, 782 small towns were identified for the provision of piped water by June 2006, and $70 \%$ of this water was to be provided by ground water sources like the deep boreholes [13]. Boreholes and shallow wells are normally installed with hand-pumps with capacity of $1 \mathrm{~m}^{3} /$ hour and their yields 


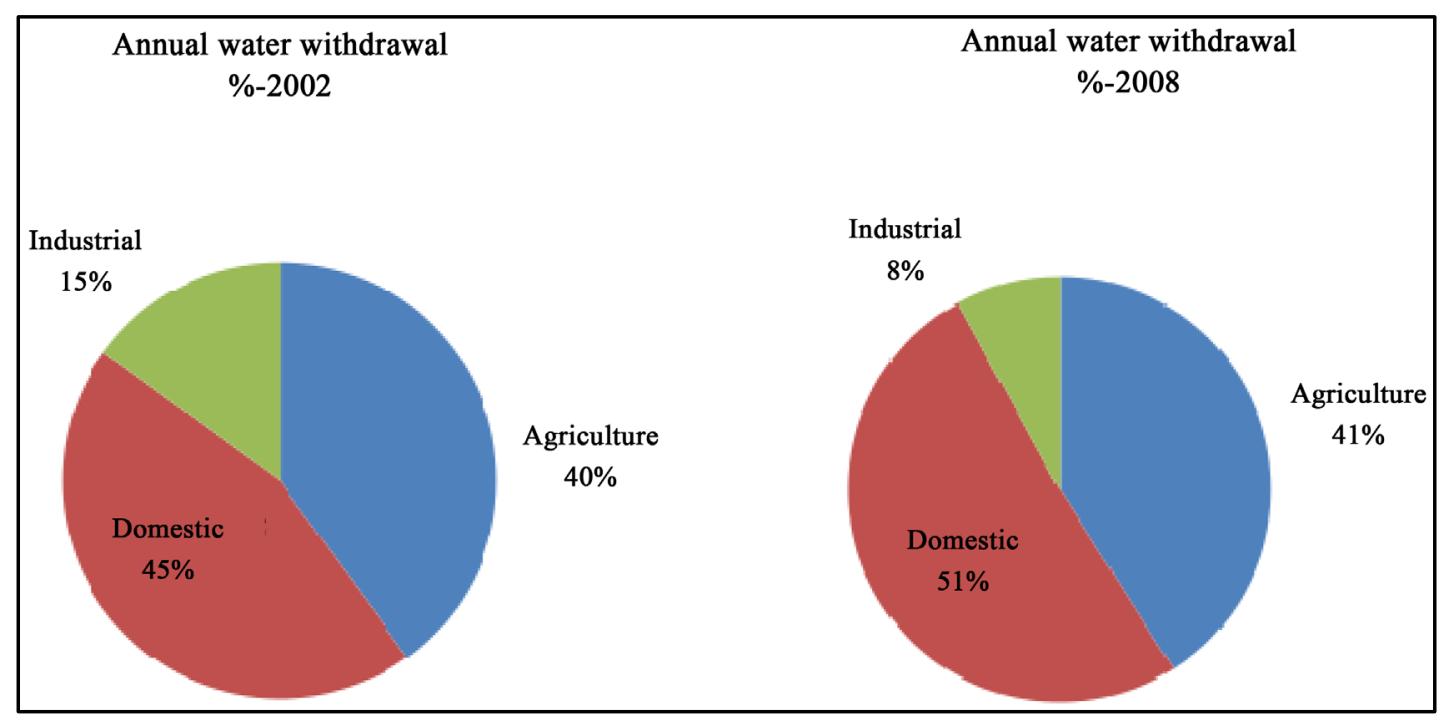

Figure 5. Water withdrawals in Uganda. (Data was sourced from WRMD quarterly reports, joint water sanitation sector program support, DWRM).

Table 6. Average sustainable groundwater for major river and lake basins.

\begin{tabular}{cccc}
\hline Drainage Basin & Area $\mathrm{km}^{2}$ & Land Area $\mathrm{km}^{2}$ & Sustainable Ground Water (mm/yr) \\
\hline Lake Edward & 18,946 & 17,855 & 20.3 \\
Lake Victoria & 61,886 & 32,924 & 24.7 \\
Lake Albert & 18,079 & 14,882 & 23.7 \\
Victoria Nile & 27,961 & 27,807 & 39.9 \\
Lake Kyoga & 57,236 & 53,899 & 36.1 \\
Albert Nile & 20,727 & 20,484 & 24.4 \\
Aswa & 27,637 & 27,635 & 17.3 \\
Kidepo & 3229 & 3228 & 6.3 \\
Miscellaneous & 5716 & 5679 & 15.0 \\
\hline
\end{tabular}

Source: Monitoring and Assessment Department, DWRM.

are usually low. Ground water has advantages like, good quality water that requires little or no treatment costs can easily be operated and managed by users, which makes investment and operational costs to be lower than those of surface based systems [13]. Boreholes with yields greater than $3 \mathrm{~m}^{3} /$ hour are thus normally considered for installation with motorized pumps for piped water supply.

In 1996 GoU initiated groundwater assessment studies, to fully understand the nature, extent and reliability of the country's groundwater resources. The study has provided Information on the distribution and behaviour of aquifers, groundwater recharge, aquifer vulnerability to pollution, impact of motorized abstraction on groundwater resources and a conceptual model of groundwater dynamics has been developed.

For example, groundwater assessments in three catchments namely Ruizi, Wamala and Victoria concluded that, groundwater resources were declining [11]. The causes of decline according to the monitoring and assessment department of the DWRM report, includes among others; climate change/global warming, changes in land-use, especially deforestation, unsustainable water withdrawals, poor catchment management, prolonged droughts, reduced rainfall in the catchment (see Table 5). This information, though still scanty, forms the basis for the current groundwater resources planning and management in the country. 


\subsection{Groundwater Recharge}

Recharge assessments have recently been carried out in Apac in northern Uganda, Mbarara in western Uganda, Wobulenzi in central Uganda, Nkokonjeru in eastern Uganda and Hoima in mid-western Uganda. Results obtained using the various methods on groundwater recharge reveal a range between 90 and $220 \mathrm{~mm}$ per annum and accounts for $7 \%$ and $20 \%$ of the average annual precipitation in Uganda [18]. Dynamically downscaled climatological data have been applied on a soil moisture balanced model to estimate ground water recharge and runoff in south-western Uganda along river Mitano [13]. Their results under the A2 emissions scenario, for the period 2070-2100, relative to 1960-1990 indicated an increase in precipitation (14\%) and a modelled potential evaporation (53\%) with a substantial increase in rain intensity [13]. Hydrological projections also gave a rise to increases in recharge (53\%) and runoff (137\%).

From the above figures it can be stated that groundwater recharge in Uganda is quite high compared to current abstraction volumes and will not be a limiting factor in groundwater development for a few years to come. However, there is a need to carry out more detailed recharge and water balance studies in the country to ensure that groundwater development is carried out in a sustainable manner.

\subsection{Ground Water Potential}

The potential of groundwater in various areas of the country is exhibited by presence of deep boreholes, shallow wells and springs. These are assessed in the paragraphs that follow.

\subsubsection{Deep Boreholes}

Deep borehole potential can be assessed by a means of a number of borehole parameters such as regolith thickness, aquifer yields and rest water levels. Uganda is characterised with a clayey regolith especially in the upper layers where relatively low permeability dominates. The regolith thickness across the country can be described as low to medium varying between $20-45 \mathrm{~m}$. This leads to medium to high ground water potential through provisional storage. Aquifer yields on the other hand vary from one part of the country to another according to the formation in which they are drilled and their degree of fracturing and weathering. For example, potential yield from deep aquifers were estimated during the AQUASTAT survey, to be above $3 \mathrm{~m}^{3} / \mathrm{hr}$ in the southwest, southeast, northwest and along the eastern border of the country [8]. In large areas of central parts of the country potential yields are between 2 and $3 \mathrm{~m}^{3} / \mathrm{hr}$, while in some areas it is below $1 \mathrm{~m}^{3} / \mathrm{hr}$ [8]. Rest water levels also give an indication of the groundwater potential of an area. Shallow water levels $(<20 \mathrm{~m})$ indicate that the aquifer has high potential for yielding groundwater while deeper water levels indicate the reverse. Rest water levels (static water levels) in the country vary between 1 and $45 \mathrm{~m}$ below ground level.

\subsubsection{Springs}

Springs occur either where the flow of unconfined groundwater is interrupted by an impermeable formation or where the head of confined groundwater is released by flow to the surface [8]. There are 2 major types of springs in Uganda namely; contact and fracture springs. Fracture springs are usually very susceptible to contamination and drying up while contact springs are more reliable [14] [16].

\subsubsection{Shallow Wells}

The potential of shallow wells is quite high, especially in the valleys. Their potential is favoured by the thick regolith that is fairly coarse grained. From Uganda's experience, shallow wells are a very reliable source of water supply to the communities although precautions need to be taken to ensure that they are not contaminated. Springs and wells are a major source of water for the country [4]. Through DWD, shallow wells have been constructed and improved to provide good quality water.

\section{Water Resources Sector Development Trends}

Much of the national documentation in Uganda refers to a series of development plans, strategies and action plans which were planned and executed to varying degrees of success, without an explicit sector policy framework before the 1980s. In the 1990s a number of guidelines were prepared and studies undertaken by government which paved the way for the review of water legislation and sector policy development process. Since then, 
GoU has taken major steps to rationalize water resources management, development and the delivery of Water and Sanitation Services (WSS). The development is aligned to achieve the Millennium Development Goal (MDG) of $62 \%$ by 2015 on water.

To achieve the set targets, the GoU has reformed the water and sanitation sector in order to ensure that services are provided and managed with improved performance and cost effectiveness. In this regard reform studies were carried out that resulted in development of Sector Strategic Investment Plans (SIPs) with appropriate policies and strategies like;

- The rural water and sanitation SIPs which aim at increasing the safe water supply coverage to $77 \%$ or $95 \%$ by 2015.

- The urban water and sanitation reform SIPs that aim at providing $100 \%$ urban population with safe water supply and sanitation by 2015.

- The water for production SIPs, which stipulates the participation of the private sector and farming community in financing this regard.

- The water resources management SIPs, which aims at promoting integrated water resources management and development at both national and local levels.

The strategies above required a Sector Wide Approach to Planning (SWAP). SWAP framework for the WSS sector was adopted at the second GoU/Donor review for the water sector in September 2002. The move towards sector wide approach called for GoU/donors to promote; uniform fund disbursement rules, uniform and stronger fund accountability rules, common indicators, joint appraisals and reviews. Since then reviews have been carried out every year to monitor progress in the water sector.

The National Water Policy was adopted in 1999 and sets the stage for water resources management and guides development efforts aimed at improving water supply and sanitation in Uganda. It promotes a new integrated approach to water management that guides the allocation of water and the associated investments. This new approach is based on the continuing recognition of the social value of water, while at the same time giving much more attention to the economic value of water. Key aspects include; application of a participatory demand driven approach to planning which promotes user ownership and management of services, backed by measures to strengthen local authorities and private institutions in implementing and sustaining water and sanitation programmes.

The National Water Policy embraces international and regional resolutions, declarations and guidelines [19] because more than $90 \%$ of Uganda's waters are trans-boundary or river courses. This therefore means that the use and development of Uganda's water resources is controlled by international laws and principles and colonial agreements.

Because much of Uganda's water ends up with the Nile, therefore, Uganda's approach to the water resources development and management is a critical element within the Nile Basin and hence requires clear trans-boundary policy and institutional frameworks and also legal and harmonized laws with riparian states.

The current strategic framework for the development and management of water resources in Uganda recognizes two important principles. First, water is fundamental, to achieving the national objective of poverty eradication through the promotion of rapid economic growth, good health, food security, and social equity. Secondly, within the regional context, according to the ministerial policy statement, cooperative development of the transboundary water resources e.g. the Nile, the Kagera, Sio-Malaba River, Lake Victoria, Lake Albert, Lake Edward and others can serve as a catalyst for a broader range of cooperation and economic integration.

\section{Water Resources Utilization in Uganda}

Water for Agriculture/irrigation: Rain fed agriculture is the most practiced land use method in the Uganda. Currently this practice is threatened with climatic variability and a fast growing population, which are impacting on food security levels. As a result national policy on agriculture aims at increasing agricultural production per unit area e.g through a more efficient use of land and water resources which will improve food security. The increase in population has increased the need to raise crops in areas that do not get enough rainfall, hence requiring irrigation. A Food and Agricultural report study in 1987, estimated the irrigation potential in Uganda to be more than 280,000 ha. If fully developed a water demand of 2.7 billion· $\mathrm{m}^{3} /$ year will be required from Uganda's water resources hence, placing a considerable demand on the national and trans-boundary water resource like the river Nile. In order to manage water fairly, the Shared Vision Program (SVP) on efficient water use for agricultural 
production was set up to establish a forum to assist stakeholders at regional, national and community levels to address issues related to efficient use of water for agricultural production in the Nile basin and link it with the trans-boundary water policy. This program provides the appropriate linkage under the Trans boundary Water Resources Program (TBWRP) being formulated with NBI-SVP for improved agricultural Production.

Water for power: Most waterpower is used to generate Hydro-Electric Power (HEP), which is used to light homes and to run factories. A study by Nile Basin Capacity Building Network (NBCBN) in 2005 estimated the hydrological resources to have a power production potential of over $2500 \mathrm{MW}$, of which over $2000 \mathrm{MW}$ is mainly concentrated on river Nile and the rest is scattered in parts of the country.

By 2005, less than $10 \%$ of this potential was exploited [20]. Of the 2000 MW potential along the river Nile, 630 MW (31.5\%) have been tapped, and the unexploited potential is well over $1300 \mathrm{MW}$ [21]. Installed capacity stands at 872 MW including thermal and hydropower plants, of which HEP contributes 621.5 MW. This shows that power supply of Uganda is almost totally dependent on hydropower. Unfortunately, installed capacity is grossly inadequate to meet the current and rapidly increasing demands. For example in 2008, the number of consumers by type was recorded at 347,433 for domestic small general service; 28,810 for commercial small general service; 324 for large industrial; 1194 for general-medium industrial and 195 for street Lighting in 2008 [22]. Given the current economic growth of 7\%, domestic power demand is expected to increase to $1130 \mathrm{MW}$ in 2023 [23]. One of the national development plan objectives is to increase power generation to between $780 \mathrm{MW}$ and $820 \mathrm{MW}$, as well as increase rural electrification by $10 \%$ and promote efficiency programmes and renewable sources countrywide.

The main sites that have been identified for the development of major schemes are all located downstream along the river Nile. The other small-scale hydropower potentials exist along the rivers draining Mt. Elgon, the extreme southwest of Uganda, rivers draining west Nile near Arua and the rivers draining the Rwenzori Mountains. The country has a big potential for medium, small and micro hydropower stations. Development of large schemes on the Nile should be the right way to go by the government of Uganda, because the markets are available in the region.

The national policy provides for regional co-operation for optimum hydropower development. For example, the Nile Basin Power Trade of NBI-SVP has the objectives of establishing the institutional means to coordinate the development of regional power markets and improve access to reliable and low cost power among the Nile Basin countries. In order for Uganda to fully exploit her hydropower potential on the Nile, this program will be the main avenue for the linkage for cooperation under the trans-boundary water policy and to also promote the benefit-sharing concept.

Water for industry: The role of water for example in industry contributed 24.2\% in 2008/2009 to the total Gross Domestic Product (GDP) and increased to $26.9 \%$ in 2010/2011 [24]. Water is highly consumed in the construction industry [25] especially during this period when the country is undergoing infrastructural development. These industrial activities (Construction, manufacturing, mining and quarrying) that consume a lot of water contributed $12.3 \%, 7.5 \%$, and $0.3 \%$ of the total GDP in 2008/09 respectively. Water, which is vital in transforming industry and eradicating poverty, will be in high demand in future, given the trend of economic growth.

Water for fish: Inland water bodies support a thriving fishing industry in Uganda. Fish catches vary from place to place, with the largest yields associated with major lakes and rivers (Table 3). According to [24] fishing activity was worth 2.9\% share of the GDP by 2008/09 fiscal year and many people are indirectly dependent on this industry. Fish is often a large part of diet of people living in the country and abroad. Tonnes of fish are also harvested from wetlands and ponds on fish farms. Fishing activities have become so popular that are fast increasing in importance and numbers that exerts pressure on water resources especially on quality of water resources.

Water for transport: People depend on water transport to carry goods for use and trade from one region to another, using boats, ferries and ship. Water transport links Ugandans living on islands with the mainland and also those involved in trade across borders towards DRC, Tanzania and Kenya. Transport as an activity though not fully developed, has impact on the quality of water resources, which requires further study.

Water for environment and tourism: Development of tourism in Uganda is a high priority area. Tourism development is dependent on the natural beauty and quality of the environment, including wetlands, range lands, lakes, rivers and the associated sceneries like the waterfalls, beaches and rare fauna species which provide an array of tourism activities. The splash and flow of water in the streams, hot springs, geysers and fountains also 
soothes and inspires many people who love being near water. Most of the recreational places in Uganda provide water sports, such as swimming, fishing, Water rafting and sailing. People also enjoy the beauty of a quiet lake, a thundering waterfall (like at Karuma, Kabalega and Budhagali) or even roaring surf. Business community in Uganda has built recreational areas along the lakes, such as Entebbe, Lutembe, Sesse-Kalangala, Kigo, Jinja where local tourism is flourishing. This study discovered that climate variability was impacting on the activities at the shores of the Lake Victoria, and the subsequent income of the entrepreneurs.

These touristic facilities generate huge financial and socio-economic benefits for the country. For example in the year 2008, a total of 844,000 tourists to the country were recorded, of which 144,000 declared their purpose of visit as leisure and holiday. And about 138,000 persons (foreign and national) visited the national parks in 2008, 190,000 in 2010 and 208,000 in 2011. Between 2010 and 2011 the industry grew by $9.4 \%$ and contributed $21 \%$ to GDP in 2011, earning the country US \$805 million in 2011/12 financial year according to the Daily Monitor Newspaper, 26.09.2012.

Water for Sanitation: This is a field of public health necessary for controlling and preventing disease. It includes personal cleanliness, sewerage treatments, waste disposal systems, water treatment and so forth. Sanitation deteriorates where water conditions are poor and uncertain which directly affects the wellbeing of communities. Likewise sewerage and sanitation service requirements increase in step with improvements in water supplies and have important health implications. Because water, health and sanitation are set targets for 2015 MDGs, African Development Bank (ADB) financed water and sanitation projects to small towns and rural areas in Uganda to the tune of USD 28 million and USD 60 million respectively [26]. GoU has also signed agreements in 2012 to finance projects to improve health services delivery and access to water and sanitation in both urban and rural areas worth USD 155.8 million of investment [27]. This development is expected to put more pressure on the water resources of the country as discussed in sections above.

Water supply: Water supply is a key factor of production in e.g. manufacturing industry, power generation, mining, construction and agriculture. It sustains the natural environment; therefore its quantity and quality are important indicators of what the country has achieved. Access to water has levelled off at $64 \%$ for rural and $77 \%$ for urban areas but set targets are 100\% and 77\% for urban and rural areas respectively by 2015 .

The challenges faced in Uganda with regard to water supply issues are: to ensure that water for both human and livestock consumption is available in sufficient quantities and quality all the time; that the demand is quantified; water is used efficiently and sanitation is promoted; and shared waters and watercourses are used and developed to meet this demand in particular with regard to the new strategy of bulk water supply.

\section{Vulnerability to Climate Change and Adaptation Strategies}

The changing climate in Uganda presents very serious national challenges and risks across various sectors such as agriculture, water resources and energy, which support the economy and the wellbeing of its people. Climate change has significant impacts, which manifest itself in form of droughts, variations in groundwater and surface water levels, melting of ice caps and incidences of diseases, high temperatures and wild fires. For example, [10] identified 8 seasonal droughts within the Lake Victoria basin in the period between 1990 and 1999. Our analysis has also established drought years and seasons in the various drainage sub-basins in Uganda (Table 4). Prominent was the 2004/5 drought period when the water level in Lake Victoria dropped by a meter below the 10 year average [28]. Droughts significantly affect the country's water resources, hydropower production and agriculture.

Cycles are observed in rainfall patterns in Uganda for the period 1940-2009. Analysis shows decades of normal and beyond normal rainfall (Figure 6) during the period of analysis. Three long spans of below normal rain are evident in the 1940s, 1960/70 and 1980s. Other particularly wet periods were experienced in early 1950s, 1960s, late 1970s and the 1990s (Figure 6). The contributing factors to the below average annual total rainfall for Uganda have not been established in this study despite the 1980s being drought years with consequences on food security for the continent [29].

From a hydrological perspective, Lake Victoria, the largest water resource exerts a big influence in Uganda's climate. The main source of water for the lake is rain, but due to rainfall anomalies, the lake has consequently displayed large and rapid changes. This has been demonstrated by [30] [31] who find a significant correlation between lake rainfall series and lake levels. A number of studies highlighted by [15] and [32] have concluded that the lake is a sensitive indicator of climate change. Models on Sensitivity of lake levels, predict a fall in le- 


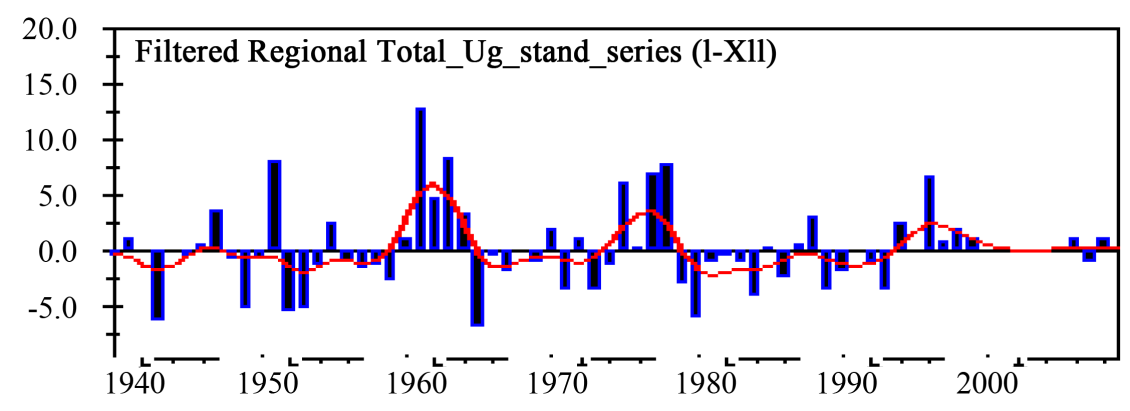

Figure 6. Regional total rainfall (mm) for the period 1940-2009.

vels during the 2021-2050, and levels pick up by 2070-2099, time horizons in both emission scenario. This circumstance is explained by the predicted decrease in direct rainfall with a corresponding increase in lake potential evaporation by 2021-2050 [15].

Melting glaciers have been a centre of attraction of late as a source of water. The interaction between glaciers and climate represents a particular sensitive process on the water resources of Uganda. A number of authors have been cited by [11] to have comprehensively studied the effect of this interaction in the Rwenzori catchment area. Recent research in the 1950s, 1990s and 2000s indicate that the area covered by alpine glacier has reduced from $7.5 \mathrm{~km}^{2}$ in 1906 to $1 \mathrm{~km}^{2}$ in 2003 on Rwenzori Mountains [33]. Between 1955 and 1990, Rwenzori ice caps according to the Sector Performance Report of 2011 have retreated by $40 \%$. This drastic trend calls for further studies and urgent response from policy makers.

The effect of deglaciation on water resources has been investigated to determine the impact of glacial melt on river discharge during the dry season and the risk of flooding during the rainy season [34]. Their findings, also held by [35] showed that current glacial recession has a negligible impact on alpine river flow since melt water discharges contribute less than $2 \%$ of the total discharge of the principal river receiving melt water (River Mubuku) at the base of Rwenzori Mountains during both dry and wet seasons. Consequently the effect of melt water has insignificant impact on the water resources, but may have adverse effect on tourism of Uganda. Melting of ice caps of the Rwenzori is expected to have an effect on water catchments downstream and eco-tourism as well as the overall economy [36].

The effects of climate change on ground water recharge and base flow in upper Ssezibwa catchment in Uganda has been studied using global climate models [17]. Projections from their study indicate that rainfall will generally increase, from $20 \%$ to $100 \%$ by the 2080 s. Simulations from the same study showed an increase in recharge, base flow and total flow in the future. The mean annual daily discharge is expected to increase by $40 \%$ $100 \%$ from the current $1.47 \mathrm{~m}^{3} / \mathrm{s}$ in the coming 20 to 80 years.

\section{Water Governance in Uganda.}

Water governance is seen as a range of political, social, economic and administrative systems that are in place to develop and manage water resources and the delivery of water services at different levels of society [37]. The manner of allocation and regulatory process and interaction in the management of water resources that embraces formal and informal institutions [38] including poverty eradication [39] are a focus of governance. Some of the necessary conditions for good governance are inclusiveness, accountability, participation, transparency, predictability and responsiveness. A major challenge is to understand how all these different processes in concert, determine certain policy outcomes and how change in governance regimes occurs.

For instance policies tend to focus on standard policy solution like liberalization and pricing of water services, which have had counter-productive results. Currently Climate change and the related increase in extreme weather events have exposed the vulnerability and lack of resilience of water resource management regimes. At the same time, policies to accommodate the prospects of climate and global change are absent. Consequently the conditions under which water resources managers have to perform have become increasingly unpredictable especially in a developing country like Uganda.

The broad strategies in Uganda for implementing activities and programs in the Water sector are articulated in the Poverty Eradication Action Plan (PEAP) of 2004. PEAP which formed the basic planning framework for the formulation and implementation of all sector policies, strategies and programs, identifies water and sanitation as 
part of the priority areas for poverty eradication. The strategies are embedded in the three pillars, namely; to increase production and competitiveness of Uganda's products to attain increased household incomes including water for production and water resources management; Strengthening security, conflict resolution and disaster management (includes water for security in north-eastern Uganda and provision of water and sanitation services; and human development among others.

Implementation of the PEAP is guided by a comprehensive sector policy and legal framework for management of the water and sanitation sector. These include: the 1995 Constitution of the Republic of Uganda, Local Governments Act Cap 243, Water Act Cap 152, and accompanying regulations, the 1998 Water Resources Regulations, the 1998 Waste Discharge Regulations, Water Supply Regulations of 1999, Sewerage Regulations of 1999, National Environment Management Authority Act Cap. 153, National Water \& Sewerage Corporation Statute Cap 317, Uganda Water Action Plan of 1995, National Water Policy of 1999, National Environment Management Policy of 1994, National Health Policy and Health Sector Strategic Plan of 1999, the 1997 National Gender Policy, and the Community Mobilisation and Empowerment Strategy of 2006.

Since Uganda ascribes to international water conventions and declarations, it has prepared a Water Action Plan (WAP). The WAP is a flexible and dynamic framework for the protection and development of Uganda's water resources in conformity with the Water Act.

The government of Uganda further developed a water policy that provides for the overall policy framework for water resources management and development. The overall objective of the water policy is "To manage and develop the water resources of Uganda in an integrated and sustainable manner, so as to secure and provide water of adequate quantity and quality for all social and economic needs of the present and future generations with the full participation of all stakeholders" [19].

The National Water Policy for Uganda identifies a need to enhance co-ordination and collaboration between the water and sanitation sub-sectors, so that they both adequately address environmental health and sanitation issues. This is done through the Water Policy Committee (WPC), Water Sector Working group (WSWG), Donor Forum, Non-Government Organisations (NGOs) forum under the umbrella of Uganda Water and Sanitation Network (UWASNET), Sector reviews by GoU and Donors and District Water and Sanitation Committee (DWSC).The policy also acknowledges the need for cooperation on trans boundary water resources management issues and promotes decentralization of water management functions. Water supply and sanitation, water for agriculture, hydropower and industrial use are priorities areas for allocation of water through planning and operation of systems.

The key player in water governance is the Ministry of Water and Environment (MWE), which has the overall responsibility of setting national policies and standards, and priorities for water development and management. It also monitors and evaluates sector development programmes to keep track of their performance, efficiency and effectiveness in service delivery. Under the Ministry there are two agencies for water sector namely; DWD as the lead agency responsible for managing water resources, coordinating and regulating all water and sanitation activities and providing support services to local Governments and other service providers. The National Water and Sewerage Corporation (NWSC) an autonomous parastatal entity established in 1972, and recognised by NWSC statute of 1995, is responsible for the delivery of water supply and sewerage services.

The other players in water governance are Ministry of Finance, Planning and Economic Development (MoFPED) mobilises funds, the Ministry of Health $(\mathrm{MoH})$ is responsible for hygiene and sanitation promotion for households, while the Ministry of Education and Sports (MoES) does similar work in primary schools, the Ministry of Gender, Labour and Social Development (MoGLSD) is responsible for gender responsiveness and community mobilisation, the Ministry of Agriculture, Animal Industry and Fisheries (MAAIF)spearheads agricultural development. This includes the use and management water for production including Irrigation, animal production and aquaculture at farm level. Local Governments (Districts, towns, Sub-Counties) are empowered by the Local Governments Act of 1997 to provide water services. Communities are responsible for demanding, planning, contributing a cash contribution to operating and maintaining rural WSS facilities. While (NGOs) and Community Based Organisations(CBOs) are active in the provision of water and sanitation services, training of communities and local governments, hygiene promotion as well as advocacy and lobbying.

Since 1993, Uganda has been undergoing a decentralization of responsibilities from central government level to district local government level. This shift of responsibility has had a profound impact on the players in the Water Supply and Sanitation (WSS) sector. Districts became the main implementation agents and the human dimension is being emphasised in governance issues. 


\section{Catchment Based Water Resources Management}

There is a lot of diversity presented in literature relating to the implementation of Integrated Water Resources Management (IWRM), especially in developing countries. This diversity is attributed to differences in institutional set up, governance structures, legal framework and level of development. The framework of IWRM stipulates that water resources are better managed at a catchment unit. This is why the WRM sub-sector reform study in Uganda recommended a paradigm shift from a centralized to a catchment based water resource management. Uganda is divided into four main management zones namely; Victoria, Kyoga, Albert and Upper Nile water management zones.

A pilot study on river Rwizi catchment area located in Victoria water management zone has revealed some aspects in the initiation of catchment management. Such as identification of threatened wetlands systems, integration of catchment management issues in district development plans, promotion of community participation, forestation, and dissemination of weather outlook/forecasts among others [40].

One of the key lessons learnt during piloting was that IWRM is better embraced in an area that is experiencing serious water resources problems. Secondly, because the process requires involvement of multiple stakeholders for its success, it involves a great deal of consultations and consequently substantial amounts of funds are required. Involving political, administrative and technical representatives in catchment management structures was found to be a viable aspect, thus it is highly encouraged.

\section{Water Resources Management Challenges and Issues}

Water resources in Uganda are estimated at $66 \mathrm{~km}^{3} /$ year corresponding to about $2800 \mathrm{~m}^{3} /$ person/year. The spatial and temporal distribution of water resource is uneven, which pauses a big challenge to their management. Some areas like those in north-eastern Uganda have less water resources while those in the central have plenty of water resources. That is why there are increasing incidences of water use conflicts in the water scarce parts of the country, especially in the cattle corridor. Pastoralists migrate from place to place in search of water and vegetation. This movement not only creates a security threat, it is also a major health hazard as diseases are transferred from one part of the country to another in this process.

There is also increasing pressure on water resources due to rapid population growth, increased urbanization and industrialization, uncontrolled environmental degradation and pollution. A combination of some of these factors is cited to be responsible for the recent landslides in eastern Uganda. This pressure still remains a big challenge to the sustainable management and development of country's water resources.

The frequent recurrence of extreme weather events (floods and droughts) and increasingly erratic rainfall are a big challenge to the management of Uganda's water resources. The variability in seasonal rainfall, has significantly affected the different socio-economic activities that are heavily dependent on rainfall.

Ground water is presently the major source of rural domestic water supply and is planned as the main source of water for small towns (40 completed and 80 new ones) and rural growth centres (800) by 2015. Some of the aquifers however, are limited in yield, extent, hydraulic characteristics, and recharge is low in certain parts of the country. The availability and quality of groundwater for larger rural water supply projects is a significant future challenge. Given the limitations of ground water supplies, it would appear that groundwater abstractions for many large projects such as irrigation and municipal water supplies might not be sustainable. There is still little knowledge on how climate change will impact on this important resource.

Given the increasing demand for water and the high rates of population growth of $3.2 \%$, it is of utmost importance that an analysis of the hydrological impacts of climate change for the country are intensified.

Despite all the above planned developments, there is still very limited knowledge of the country's groundwater resources, making it difficult to guarantee sustainable groundwater development for the current and future needs.

Groundwater recharge varies considerably across the country and is extremely sensitive to land use and the amount and intensity of precipitation falling in a given area. However, due to inadequate data and resources, very few groundwater recharge assessments have been carried out in Uganda and thus recharge estimates for most areas remain unknown.

Government should be aware that, the development of hydropower schemes, though a non-consumptive use, creates reservoirs, which have adverse effects and environmental consequences on water resources. These include; Siltation/sedimentation and aquatic weed encroachment in the reservoir, diminished downstream river 
discharge, eutrophication in reservoirs due to domestic and industrial waste, increased loss of water due to evaporation and others.

The unique geographical location of Uganda in the Nile Basin, i.e. being a lower and an upper riparian state imposes constraints and responsibilities to the country [41]. As a country it would be affected by the use of the water both in quantity and in quality by the riparian countries.

Another setback in Uganda's effort especially to exploit HEP potential is the current colonial agreement of the agreed curve policy [41]. This colonial agreement has been rejected by Uganda even though the main beneficiaries of the agreement are still upholding it. It is therefore expected that regulation of Lake Victoria with a more scientific friendly policy supported by Decision Support Systems (DSS) may overcome this problem.

The challenges that Uganda faces in this respect include: failure to regulate Lake Victoria with a better regulatory policy, fluctuation of levels of lake Victoria and other equatorial lakes in the Nile Basin due to climatic change and variability, maintenance of water quality to be free of aversive weeds, sedimentation etc.

\section{Conclusions}

Priority of Uganda's water resources utilization and development is given to domestic water supply for both human consumption and livestock. Rural domestic water demand is by far greater than the urban demand because about $80 \%$ of the country's population is rural. Currently the rural population is dependent on ground water development or rainwater harvesting to meet their needs. Given the MDG water targets and GoU water development programmes, Uganda will resort to the utilization of the watercourses and the shared water bodies to satisfy rural water demand sooner than later. The water supply sector is under expansion and small-scale irrigation is being promoted and may in the future be of increased importance, but rainfall, which is a major source of water, is on a decrease as water demand increases. Detailed assessments are thus necessary on ground water resources, groundwater recharge and water balance.

Evidence shows that, rate of access to domestic water for rural and urban water populations had levelled off at $63 \%$ and $77 \%$ for the year 2007/2008 [24]. Major source of water for the country are the springs and wells. The new national strategy of bulk water supply is to meet rural settings demands including demands of water for livestock (WSS sector working group report, 2006). The biggest challenge is that this demand is not quantified, not forgetting that Uganda is both a downstream and an upstream riparian state.

\section{References}

[1] Kumar, R., Singh, R.D. and Sharma, K.D. (2005) Water Resources of India. Current Science, 89, $794-811$.

[2] Kundzewicz, Z.W., Mata, L.J., Arnell N.W., Döll, P., Kabat, P., Jiménez, B., Miller, K.A., Oki, T., Sen, Z. and Shiklomanov, I.A. (2007) Freshwater Resources and Their Management. Climate Change 2007: Impacts, Adaptation and Vulnerability. In: Parry, M.L., Canziani, O.F., Palutikof, J.P., van der Linden, P.J. and Hanson, C.E., Eds., Contribution of Working Group 11 to the Fourth Assessment Report of the Intergovernmental Panel on Climate Change, Cambridge University Press, Cambridge, 173-210.

[3] WRMD (2004) The Year-Book of Water Resources Management Department (WRMD) 2002-2003. Entebbe.

[4] UN-WWAP (2006) Uganda National Water Development Report; Prepared for the 2nd UN World Water Development Report "Water a Shared Responsibility" UN-WATER, WWAP/2006/9. World Water Assessment Programme (WWAP).

[5] Asadullah, A., Mcintyre, N. and Kigobe, M. (2008) Evaluation of Five Satellite Products for Estimation of Rainfall over Uganda. Hydrological Sciences Journal, 53, 1137-1150. http://dx.doi.org/10.1623/hysj.53.6.1137

[6] NEMA (2008) State of Environment Report for Uganda. National Environment Management Authority (NEMA), Kampala.

[7] Anyah, R.O. and Semazzi, F.H.M. (2004) Simulation of the Sensitivity of Lake Victoria Basin Climate to Lake Surface Temperatures. Theoretical and Applied Climatology, 79, 55-69. http://dx.doi.org/10.1007/s00704-004-0057-4

[8] FAO (2005) Uganda-AQUASTAT Survey, Irrigation in Africa in Figures. FAO Water Reports, Rome. http://www.fao.org/nr/water/aquastat/countries_regions/uganda/index.stm

[9] NEMA (1998) State of Environment Report for Uganda. National Environment Management Authority (NEMA), Kampala.

[10] DWRM (2011) A Case Study of River Rwizi, Lake Wamala, Lake Victoria Catchments and Representative Ground Water Monitoring Stations. Water Resources Monitoring and Assessment Division. Directorate of Water Resources 
Management (DWRM) Entebbe, Uganda.

[11] Mölg, T., Georges, C. and Kaser, G (2003) The Contribution of Increased Incoming Shortwave Radiation to the Retreat of the Rwenzori Glaciers, East Africa, during the 20th Century. International Journal of Climatology, 23, 291303. http://dx.doi.org/10.1002/joc.877

[12] Awange, J.L., Ogalo, L., Bae, K.-H., Were, P., Omondi, P., Omute, P. and Omullo, M. (2008) Falling Lake Victoria Water Levels: Is Climate a Contributing Factor? Climate Change, 89, 281-297. http://dx.doi.org/10.1007/s10584-008-9409-X

[13] Mileham, L., Taylor, R.G., Todd, M., Tindimugaya, C. and Thompson, J. (2009) The Impact of Climate Change on Groundwater Recharge and Runoff in a Humid, Equatorial Catchment: Sensitivity of Projections to Rainfall Intensity. Hydrological Sciences Journal, 54, 727-738. http://dx.doi.org/10.1623/hysj.54.4.727

[14] Taylor, R.G. and Howard, K.W.F. (1996) Groundwater Recharge in the Victoria Nile Basin of East Africa: Support for the Soil-Moisture Balance Method Using Stable Isotope and Flow Modelling Studies. Journal of Hydrology, 180, 3153. http://dx.doi.org/10.1016/0022-1694(95)02899-4

[15] Tate, E., Suitcliffe, J., Conway, D. and Farquharson, F. (2004) Water Balance of Lake Victoria: Update to 2000 and Climate Change Modelling to 2100. Hydrological Sciences Journal, 49, 563-574.

[16] Tindimugaya, C. (2006) Overview of Groundwater Development in Uganda. Proceedings of the Workshop for Groundwater Professionals in Uganda, Kampala, 25 August 2006, Unpublished.

[17] Nyenje, P.M. and Batelaan, O. (2009) Estimating the Effects of Climate Change on Groundwater Recharge and Baseflow in the Upper Ssezibwa Catchment, Uganda. Hydrological Sciences Journal, 54, 713-726. http://dx.doi.org/10.1623/hysj.54.4.713

[18] Tindimugaya C (2005) Groundwater Resources Management in Urban Areas of Uganda: Experiences and Challenges. Conference Paper Maximizing the Benefits from Water and Environmental Sanitation. Proceedings of the 31st WEDC Conference, Kampala, 31 October-4 November 2005, 311-313.

[19] Ministry of Water, Lands and Environment (1999) The National Water Policy. MWLE, Kampala.

[20] NBCBN (2005) Small Scale Hydropower for Rural Development. Hydropower Development Research Cluster, Group 1, Nile Basin Capacity Building Network NBCBN-RE.

[21] ERA (2009) Development and Investment Opportunities in Renewable Energy Resources in Uganda. Electricity Regulatory Authority, Kampala.

[22] Umeme (2011) Umeme Annual Report and Financial Statements for the Year Ended December 2011. Kampala.

[23] Kasita, I. (2011) Electricity Demand to Triple by 2023. The New Vision, Kampala.

[24] MOFPED (2011) Annual Economic Performance Report 2010/11. Directorate of Economic Affairs, Ministry of Finance, Planning and Economic Development, Kampala.

[25] UBOS (2009) Uganda Bureau of Statistics, 2009 Statistical Abstracts. Kampala. www.ubos.org.

[26] African Development Bank (2010) The African Development Bank in Action, Activities in the Water and Sanitation Sector in Uganda: Overview and Key Elements of Interventions. Water and Sanitation Department of the African Development Bank.

http://www.afdb.org/fileadmin/uploads/afdb/documents/Projects-and-Operations/9_AFDB_watsan_UG

[27] African Development Bank (2012) AFDB Promotes Improved Access to Water, Sanitation and Health Services in Rural and Urban Uganda. African Development Bank Group.

http://www.afdb.org/en/news-and-events/article/afdb-promotes-improved-access-to-water-sanitation-and-health-servic es-in-rural-and-urban-uganda-8771/

[28] Kull, D. (2006) Connections between Recent Water Level Drops in Lake Victoria, Dam Operations and Drought. http://www.internationalrivers.org/files/attached-files/full report pdf.pdf

[29] Hulme, M. (1992) Rainfall Changes in Africa: 1931-1960 to 1961-1990. International Journal of Climatology, 12, 685-699. http://dx.doi.org/10.1623/hysj.54.4.713

[30] Hastenrath, S. (2001) Variations of East African Climate during the Past Two Centuries. Climatic Change, 50, 209217. http://dx.doi.org/10.1023/A:1010678111442

[31] Mistry, V.V. and Conway, D. (2003) Remote Forcing of East African Rainfall and Relationships with Fluctuations in Levels of Lake Victoria. International Journal of Climatology, 23, 67-89. http://dx.doi.org/10.1002/joc.861

[32] Nicholson, S.E., Yin, X. and Ba, M.B. (2000) On the Feasibility of Using a Lake Water Balance Model to Infer Rainfall: An Example from Lake Victoria. Hydrological Science Journal, 45, 75-95. http://dx.doi.org/10.1080/02626660009492307

[33] Taylor, R.G., Mileham, L., Tindimugaya, C. and Mwebembezi, L. (2009) Recent Glacial Recession and Its Impact on 
Alpine River Flow in the Rwenzori Mountains of Uganda. Journal of African Earth Sciences, 55, 205-213. http://dx.doi.org/10.1016/j.jafrearsci.2009.04.008

[34] Kaser, G., Hardy, D.R., Mölg, T., Bradley, R.S. and Hyera, T.M. (2004) Modern Glacier Retreat on Kilimanjaro as Evidence of Climate Change: Observations and Facts. International Journal of Climatology, 24, 329-339. http://dx.doi.org/10.1002/joc.1008

[35] MWE (2011) Uganda Water and Environment Sector Performance Report 2011, Ministry of Water, Lands and Environment, Kampala.

[36] GWP (2000) Integrated Water Resources Management. Global Water Partnership (GWP) Technical Advisory Committee, Background Paper No.4.

[37] Rogers, P. and Hall, A.W. (2003) Effective Water Governance. Technical Committee Background Papers No.7, Global Water Partnership (GWP).

[38] Turton, A.R., Hattingh, H.J., Maree, G.A., Roux, D.J., Claassen, M. and Strydom, W.F., Eds. (2007) Governance as a Trialogue: Government-Society-Science in Transition. Springer-Verlag Berlin, Heidelberg. http://dx.doi.org/10.1007/978-3-540-46266-8

[39] Sewagudde, S. (2011) Catchment Based Water Resources Management: Uganda’s Journey to Taking the IWRM Concept to the Grass Root. Wash Watch, 2, 19-23.

[40] Human Development Report, HDR (2006) Beyond Scarcity: Power, Poverty and Global Water Crisis. Palgrave Macmillan, New York.

[41] NEMA (1996) State of the Environment Report for Uganda 1996. National Environment Management Authority (NEMA), Kampala. 
Scientific Research Publishing (SCIRP) is one of the largest Open Access journal publishers. It is currently publishing more than 200 open access, online, peer-reviewed journals covering a wide range of academic disciplines. SCIRP serves the worldwide academic communities and contributes to the progress and application of science with its publication.

Other selected journals from SCIRP are listed as below. Submit your manuscript to us via either submit@scirp.org or Online Submission Portal.
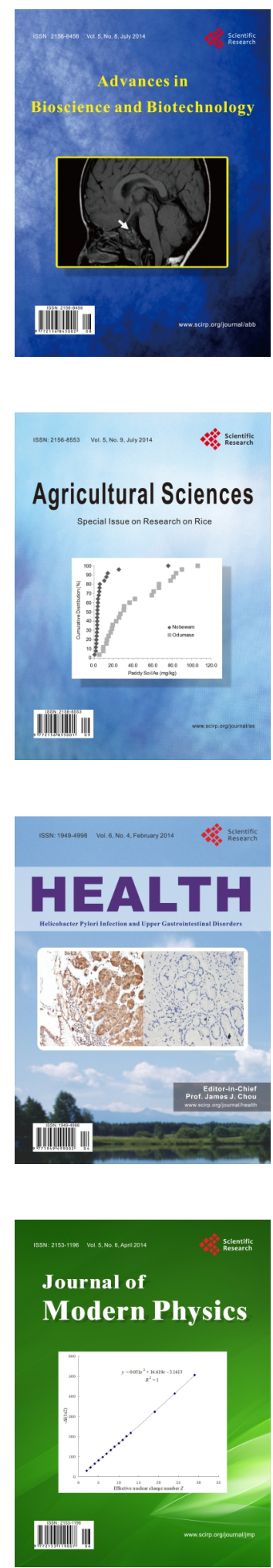
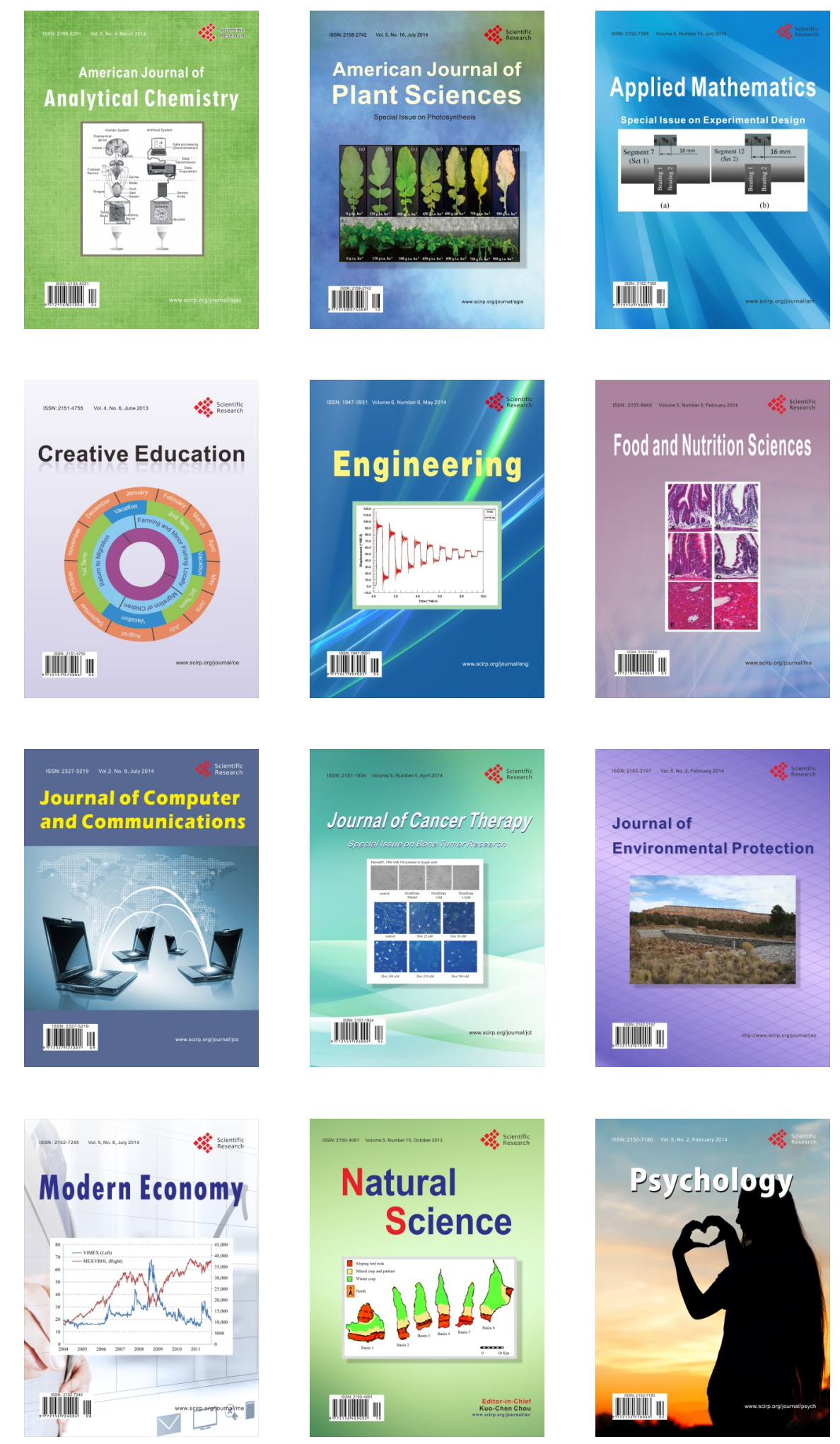